\title{
STUDI JENIS DAN KELIMPAHAN TERIPANG (HOLOTHUROIDEA) DI EKOSISTEM PADANG LAMUN PERAIRAN DESA KAHYAPU PULAU ENGGANO
}

\author{
Oleh \\ Oktamalia, Dewi Purnama, Dede Hartono \\ Jurusan IImu Kelautan Fakultas Pertanian Universitas Bengkulu, Bengkulu \\ Email :okta.malia@mail.co.id \\ Received July 2016, Accepted August 2016
}

\begin{abstract}
ABSTRAK
Penelitian ini dilakukan di perairan pantai Kahyapu Pulau Enggano Provinsi Bengkulu pada bulan September sampai November 2013. Hasil pengamatan ditemukan 7 jenis yang termasuk kedalam kelas Holothuroidea, dengan dua ordo yaitu Apodida dan Aspidochirotida dan dua famili yaitu Holothuridea dan Synaptidae, serta 4 Genus yaitu Opheodesoma, Synapta, Eupta, dan Holothuria. Dengan kelimpahan tertinggi pada bulan September dan November stasiun 1 sebanyak 153,33 dan 520 ind/ha, terendah stasiun 1 dan 2 sebanyak 13,33 ind/ha. Pada stasiun 3 masing-masing 13,33 ind/ha. Pada bulan September maupun November kepadatan tertinggi masing-masing berjumlah 0,1- 1,333 ind $/ 25 \mathrm{~m}^{2}$, dan $1,071-2,933 \mathrm{ind} / 25 \mathrm{~m}^{2}$. Indeks dominasi bulan September dan November berkisar antara 0,343-1 dan 0,120-0,524. Indeks keanekaragaman bulan September dan November berkisar antara 0-0,918 dan 1,52-1,979. Indeks keseragaman bulan September dan November berkisar antara 0-0,918 dan 0,576-0,765. Hasil pengukuran faktor abiotik didapatkan suhu rata-rata $27,63^{\circ} \mathrm{C}$, kecepatan arus rata-rata $0,2 \mathrm{~m} / \mathrm{s}$, kedalaman rata-rata $25-33 \mathrm{~cm}$, kecerahan mencapai $100 \%$, salinitas rata-rata 30,53 ppm, derajat keasaman $(\mathrm{pH})$ rata-rata 6,78. kandungan padatan tersuspensi berkisar antara 1,720-1,950 mg/l dan kandungan bahan organik dalam sedimen berisar antara 1,63-3,86 \%.
\end{abstract}

kata kunci : teripang, ekosistem padang lamun.

\section{ABSTRACT}

This research was held in the water of Kahyapu coast of Enggano Island, Bengkulu, in September to November 2013. The observation was resulted in the discovering of 7 species which belong to class Holothuroidea in 2 ordos of Apodida dan Aspidochirotida, and in 2 families of Holothuridea dan Synaptidae, along with 4 genuses of Opheodesoma, Synapta, Eupta, dan Holothuria with the highest profusion was in station 1 in September and November as much as 153,33 ind/ha dan $520 \mathrm{ind} / \mathrm{ha}$. The lowest profusion was in September from station 1 and 2 as much as 13,33 ind/ha. in station 3 with average of 13,33 ind/ha each. Either in September or November 0,1-1,333 ind $/ 25 \mathrm{~m}^{2}$, and 1,071-2,933 ind $/ 25 \mathrm{~m}^{2}$. Domination index in September and November was around 0,343-1 and 0,120 $-0,524$ as for heterogeneity index was around $0-0,918$ and $1,52-1,979$ and homogeneity index was $0-0,918$ and $0,576-0,765$. As the result of abiotic factors measuring was obtained that average temperature was $27,63^{\circ} \mathrm{C}$, the average of currents celerity was 0,2 $\mathrm{m} / \mathrm{s}$, average depth was $25,33 \mathrm{~cm}$, brightness level reached $100 \%$, average salinity was $30,53 \mathrm{ppm}$, and average acidity degree $(\mathrm{pH})$ was 6,78 . of suspended concentration was around $1,720-1,950 \mathrm{mg} / \mathrm{l}$ and the contents of organic substance in sediment was around $1,63-3,86 \%$.

keyword : sea cucumber, seagrass field ecosystem. 


\section{PENDAHULUAN}

Laut merupakan habitat dari berbagai hewan dan tumbuhan yang mempunyai peran dan fungsi masing-masing. Indonesia merupakan wilayah yang memiliki potensi laut yang cukup besar, salah satunya adalah Teripang.

Teripang tersebar di seluruh lautan di berbagai belahan dunia, salah satunya di Indonesia. Di Indonesia, teripang (Holothuroidea) tersebar di seluruh perairan laut, mulai dari Barat sampai ke Timur. Hewan ini ditemukan hampir di seluruh pantai, mulai dari daerah dangkal sampai laut dalam, salah satunya di perairan Bengkulu.

Daerah penyebaran teripang di Indonesia cukup luas terutama di daerah terumbu karang, perairan yang berdasar pasir, berbatu karang dan pasir bercampur lumpur(Widodo $d k k$, 1998). Indonesia adalah pengekspor teripang terbesar di dunia, terutama diekspor ke China, Jepang, Korea, Singapore, Taiwan, dan Australia. Teripang yang di ekspor dalam bentuk kering (Al-Rashdi et al., 2007).

\section{Lokasi Penelitian}

\section{METODELOGI PENELITIAN}

Penelitian ini telah dilaksanakan di perairan Desa Kahyapu Pulau Enggano Provinsi Bengkulu (Gambar 2). Penelitian dilakukan kurang lebih selama 3 (tiga) bulan yaitu pada bulan September - November 2013

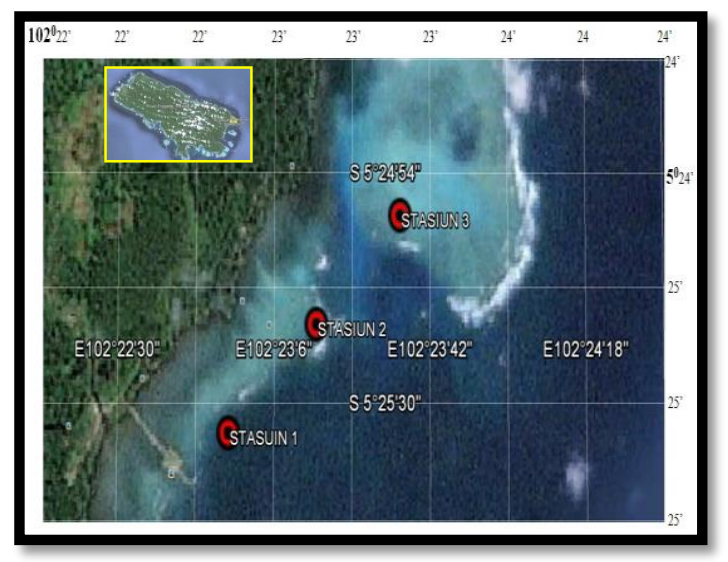

Gambar 1. Peta lokasi penelitian (Sumber: google earth).

\section{Cara Penelitian}

Penelitian di lapangan dilakukan pada 3 stasiun yaitu 1, 2 dan 3. Pada tiap stasiun dipasang 3 buah transek garis (line transec) sepanjang $2500 \mathrm{~m}$ tegak lurus garis pantai. Pada setiap transek garis digunakan metode transek kuadrat atau (systematic random) yang berukuran $5 \times 5 \mathrm{~m}$ sebanyak 10 kuadrat. jarak antara garis $200 \mathrm{~m}$, jarak atara plot 50 $\mathrm{m}$. Sampel teripang di cari setiap plot. waktu yg sama mengukur Parameter fisika-kimia yang meliputi suhu, derajat kecepatan arus, kecerahan, kedalaman, salinitas dan derajat keasaman $(\mathrm{pH})$. Selain itu juga di ambil sampel air laut dan sedimen kemudian dianaisis guna men-dapatkan data tentang padatan tersusensi dan kandungan bahan organik sedimen. Analisis sampel air laut menggunakan prosedur Alaert dan Santika (1987) sedangkan analisis kandungan bahan organik sedimen di laboraotium menggunakan prosedur Peet (1993)

Semua spesies teripang yang ditemukan diidentifikasi menggunakan buku Cannon and Silver (1940). Analisis data kelimpahan dihitung menggunakan rumus menurut Misra (1973) Brower dan Zar (1977). Kepadatan populasi dihitung menggunakan rumus menurut Krebs (2001) Indeks Dominasi dihitung menggunakan rumus menurut Odum (1971). Indeks keanekaragaman dan keseragaman dihitung menggunakan rumus menurut (Bengen, 2000). 


\section{HASIL DAN PEMBAHASAN}

Pulau Enggano merupakan salah satu pulau yang keliling luarnya berupa kawasan pantai. Pulau Enggano terletak di Samudra Hindia pada koordinat 5 ${ }^{\circ} 31^{\prime} 13^{\prime \prime} \mathrm{LS}, 102^{\circ} 16^{\prime}$ 0" BT. Pulau Enggano merupakan satu kecamatan yang termasuk wilayah pemerintah kabupaten Bengkulu Utara, Provinsi Bengkulu, dari kota Bengkulu, Pulau Enggano berjarak sekitar $175 \mathrm{~km}$ atau $100 \mathrm{~km}$ dari garis pantai. Pulau- pulau kecil lainnya yang berada di wilayah yang sama yang telah diberi nama antara lain Pulau Merbau,

Pulau Bangkai, dan Pulau Dua. Pulau Enggano memiliki panjang $45 \mathrm{~km}$ dan lebar $17 \mathrm{~km}$ (Bappeda, 2004).

Berdasarkan hasil indentifikasi sampel teripang pada lokasi penelitian d temukan 7 jenis teripang di perairan pantai Desa Kahyapu Pulau Enggano yang termasuk ke dalam kelas Holothuroidea, dengan dua ordo yaitu Apodida dan Aspidochirotida dan dua famili yaitu Holothuridea dan Synaptidae, serta 4 Genus yaitu Opheodesoma, Synapta, Eupta, dan Holothuria.

\section{Jenis dan Jumlah Teripang}

Tabel 1. Jumlah individu teripang yang ditemukan pada setiap stasiun di perairan Desa Kahyapu pulau Enggano.

\begin{tabular}{llcccccc}
\hline \multirow{2}{*}{ No } & \multirow{2}{*}{ Jenis teripang } & \multicolumn{5}{c}{ Jumlah individu teripang } \\
\cline { 3 - 8 } & & \multicolumn{5}{c}{ September } & \multicolumn{3}{c}{ November } \\
\cline { 2 - 8 } & Opheodesoma spectabilis & 3 & - & - & 34 & 17 & - \\
\hline 1 & St. 2 & St. 3 & St. 1 & St. 2 & St. 3 \\
\hline 2 & Synapta maculata & 19 & 1 & - & 39 & 33 & 14 \\
\hline 3 & Euapta godeffroyi & 13 & - & - & 4 & 6 & 1 \\
\hline 4 & Holothuria atra & 3 & 2 & 5 & 9 & 10 & 31 \\
\hline 5 & Holothuria scabra & 1 & - & - & 1 & 2 & 1 \\
\hline 6 & Holothuria loucospilota & 1 & - & - & - & - & - \\
\hline 7 & Hoothuria impatiens & - & - & - & 1 & 3 & - \\
\hline Jumlah & & 40 & 3 & 5 & 88 & 71 & 47 \\
\hline
\end{tabular}

Keterangan

$(-)=$ Tidak ditemukan

\section{Kelimpahan Jenis Teripang}

Kelimpahan jenis teripang yang ditemukan pada tiap stasiun pada bulan September dan November di perairan Desa Kahyapu Pulau Enggano, dapat dilihat pada Tabel 2.

Tabel 2. Jenis dan kelimpahan teripang yang ditemukan tiap stasiun pengamatan.

\begin{tabular}{clcccccc}
\hline \multirow{2}{*}{ No } & Jenis teripang & \multicolumn{6}{c}{ Kelimpahan (Ind/ha) } \\
\cline { 2 - 8 } & St.1 & St. 2 & St. 3 & St. 1 & St. 2 & St. 3 \\
\cline { 2 - 8 } 1 & $\begin{array}{l}\text { Opheodesoma } \\
\text { spectabilis }\end{array}$ & 40 & 0 & 0 & 453,333 & 226,666 & 0 \\
\hline 2 & $\begin{array}{l}\text { Synapta } \\
\text { maculata }\end{array}$ & 253,333 & 13,333 & 0 & 520 & 440 & 186,666 \\
\hline 3 & $\begin{array}{l}\text { Euapta } \\
\text { godeffroyi }\end{array}$ & 173,333 & 0 & 0 & 53,333 & 80 & 13,333 \\
\hline 4 & $\begin{array}{l}\text { Holothuria atra } \\
\text { Holothuria }\end{array}$ & 13,333 & 0 & 0 & 13,333 & 26,666 & 13,333 \\
\hline 5 & $\begin{array}{l}\text { Holomber } \\
\text { scabra }\end{array}$ & 13,333 & 0 & 0 & 0 & 0 & 0 \\
\hline 6 & $\begin{array}{l}\text { Holothuria } \\
\text { loucospilota }\end{array}$ & 13,666 & 66,666 & 120 & 133,333 & 413,333 \\
\hline
\end{tabular}




\begin{tabular}{cccccccc}
\hline 7 & $\begin{array}{c}\text { Hoothuria } \\
\text { impatiens }\end{array}$ & 0 & 0 & 0 & 13,333 & 40 & 0 \\
\hline Jumlah & 533,333 & 40 & 66,666 & 1173,333 & 946,666 & 626,666 \\
\hline
\end{tabular}

Keterangan

$(-)=$ Tidak ditemukan.

Pada stasiun 1 dan 2 baik pada bulan September maupun November, jenis yang memiliki kelimpahan tertinggi yaitu jenis Synapta maculata tingginya kelimpahan jenis Synapta maculata pada stasiun 1 dan stasiun 2 baik pada bulan September maupun November diduga karena jenis Synapta maculata ini merupkan jenis non-komersil yang tidak ditangkap oleh para nelayan sehingga dapat berkembang lebih baik dibandingkan teripang jenis lain. Menurut Basuki dkk., (1999), bahwa jenis Synapta maculata merupakan jenis yang tidak bernilai ekonomis penting sehingga menyebar dan dapat berkembang lebih baik dibandingkan jenis lainnya.

Pada stasiun 3 baik pada bulan September maupun November jenis yang memiliki kelimpahan tertinggi yaitu jenis $H$. atra dan ditemukannya pada stasiun 2 bulan September, hal ini diduga karena kondisi perairan pada stasiun 3 berupa laut terbuka. Menurut Wirasti (1990), H. atra banyak dijumpai pada tempat yang terbuka.

Secara keseluruhan kelimpahan jenis $H$. leucospilota memiliki kelimpahan rendah dari semua stasiun pengamatan baik pada bulan September maupun November. Hal ini diduga karena jenis ini termasuk jenis yang bernilai ekonomis sedang, Menurut Bruckner (2003) dan Conand (2004) dalam Darsono (2005), bahwa perburuan teripang tidak saja pada jenis-jenis yang harganya mahal, tetapi juga terhadap jenis-jenis teripang yang murah.

Selain jenis $H$. Leucospilota, jenis $H$. scabra juga memiliki kelimphan rendah. Hal ini karena jenis ini termasuk jenis yang ekonomis dan termasuk dalam katagori utama, relatif mahal jadi jenis ini dan banyak ditangkap sehingga pada saat pengamatan jenis ini hanya sedikit ditemukan. Menurut Darsono (1995), $H$. scabra merupakan jenis teripang yang termasuk dalam katagori utama, relatif mahal.

Untuk jenis $H$. impantiens dan Eupta godeffroyi pada stasiun 1 dan 3 bulan November, meskipun bukan merupakan jenis ekonomis akan tetapi memiliki kelimpahan yang tergolong rendah. Nontji (1993), menjelaskan bahwa jenis teripang (ordo) Aspidochirotida dan Apodida pada siang hari hidupnya membenamkan diri dalam pasir dan hanya menampakkan tentakelnya.

\section{Kepadatan Populasi}

Kepadatan teripang menunjukan keberadaan suatu spesies dalam suatu ekosistem tersebut. Pada bulan September maupun November Kepadatan Stasiun 1, 1,333 dan 2,933 ind $/ 25 \mathrm{~m}^{2}$. Stasiun $2,0,1$ dan 2,366 ind $/ 25 \mathrm{~m}^{2}$. Stasiun $3,0,166$ dan $1,566 \mathrm{ind} / 25 \mathrm{~m}^{2}$.

Tingginya kepadatan populasi teripang pada stasiun 1, baik pada bulan September maupun November diduga selain perairan yang jernih dan stasiun ini banyak ditumbuhi jenis lamun Enhalus sp. Menurut Yusron (2003), jenis Synapta maculata memiliki kemampuan untuk menempati berbagai habitat sehingga lebih banyak pula kesempatan berkembang.

Rendahnya kepadatan populasi baik pada bulan September maupun November pada stasiun 2 dan 3 diduga karena akibat penangkapan teripang secara terus menerus oleh nelayan.

\section{Indeks, Dominasi, Keanekaragaman dan Keseragaman}

Jenis teripang yang ditemukan di Desa Kahyapu Pulau Enggano secara keseluruhan terdapat perbedaan dari hasil pengamatan antara bulan September dan Bulan November dapat dilihat pada Gambar 2 dan 3. 


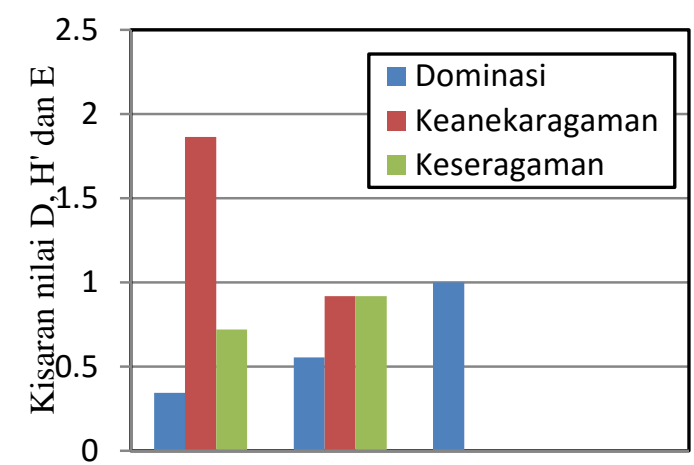

Stasiun 1 Stasiun 2 Stasiun 3

Gambar 2. Nilai indeks hasil pengamatan bulan September.

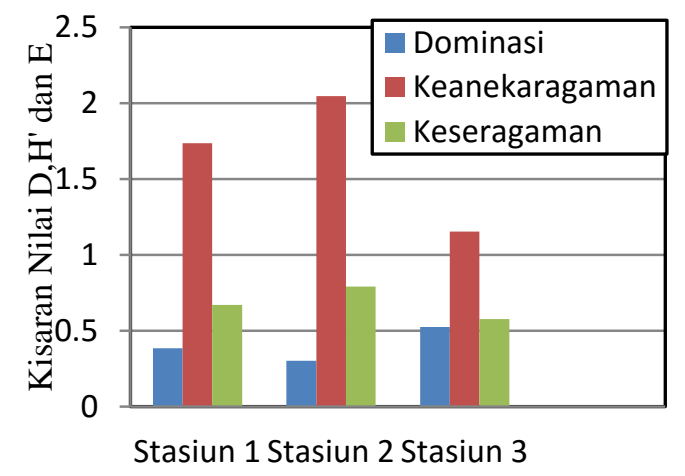

Gambar 3. Nilai indeks hasil pengamatan pada bulan November.

Tingginya nilai indeks dominasi pada stasiun 3 baik bulan September maupun November diduga karena habitat kedua stasiun hampir sama, yaitu ditumbuhi lamun yang cukup jarang, subtrat lumpur berpasir dan patahan-patahan karang mati pada bulan September di stasiun 3 hanya ditemukan 1 spesies saja yaitu jenis $H$. atra dengan nilai indeks dominasi 1 dan pada bulan November ditemukan empat spesies dengan indeks dominasi 0,524. Menurut katagori Odum (1971), bahwa nilai indeks dominasi $0,75<\mathrm{C} \leq$ 1,00 berarti adanya jenis teripang yang medominasi dalam komunitas, sedangkan nilai indeks dominasi $0,50<\mathrm{C} \leq 0,75$ menunjukkan dominasi jenis sedang.

Rendahnya nilai indeks dominasi pada stasiun 1 bulan September yaitu dengan rata-rata 0,343 dan pada stasiun 2 bulan November yaitu dengan rata-rata 0,302 diduga karena saat pengamatan selain perairan tenang, banyak terdapat tumbuhan lamun dan subtratnya pasir halus sehingga pada saat pengamatan jenis teripang yang ditemukan lebih banyak. Menurut katagori Odum (1971), bahwa nilai indeks dominasi $=0,00<C \leq 0,50$ berarti dominasi jenis rendah.

Secara keseluruhan indeks keanekaragaman teripang di perairan Desa Kahyapu Pulau Enggano di katagorikan rendah dengan nilai $\leq 2,0$. Menurut katagori indeks keanekaragaman Bengen (2000), jika nilai $H^{\prime} \leq 2,0$ menunjukan katagori rendah. Rendahnya indeks keanekaragaman diduga selain kondisi lingkungan, banyaknya aktivitas para nelayan yang mengambil teripang terus menerus sehingga menyebabkan populasi teripang rendah. 
Tingginya nilai indeks keseragaman pada stasiun 2 baik bulan September maupun November diduga kondisi perairannya cukup baik dan mendukung biota di dalamnya. Menurut Krebs (1978) dalam Suci dkk., (2012), bahwa semain tinggi nilai indeks keseragaman (mendekati 1) menandakan kandungan tiap jenis mengalami perbedaan, selanjutnya Odum (1971), menjelaskan semakin besar nilai E, maka keseragaman populasi semakin besar, penyebaran individu tiap spesies merata atau tidak ada spesies yang mendominasi.

Rendahnya nilai indeks keseragaman pada stasiun 3 bulan September dan November diduga pada stasiun 3 perairannya langsung berhubungan dengan laut terbuka sehingga langsung berasosiasi dengan terumbu karang dan memiiliki subtrat pasir kasar karena banyak terdapat patahan - patahan karang mati sehingga teripang yang hidup di perairan ini hanya spesies yang tertentu. Menurut Krebs (1989) dalam Suci dkk., (2012), bahwa nilai indeks menunjukkan penyebaran individu, apabila nilai keseragaman mendekati 0 berarti keseragamannya rendah karena ada jenis yang mendominasi.

\section{Kondisi Lingkungan Teripang}

Hasil pengukuran parameter kualitas air yang dilakukan pada bulan September dan November diperoleh data suhu rata-rata $27,63{ }^{\circ} \mathrm{C}$, kecepatan arus rata-rata $0,2 \mathrm{~m} / \mathrm{s}$, kedalaman rata-rata $25,33 \mathrm{~cm}$, kecerahan mencapai $100 \%$, salinitas rata-rata $30,53 \mathrm{ppm}$, derajat keasaman $(\mathrm{pH})$ rata-rata 6,78. Secara keseluruhan kondisi fisika-kimia perairan di perairan Desa Kahyapu Pulau Enggano dapat mendukung kehidupan dan pertumbuhan teripang.

\section{Kandungan Bahan Organik dalam Sedimen}

Bahan organik dihasilkan oleh organsime hidup baik hewan maupun tumbuhan melalui peroses metabolisme dan hasil pembusukan lalu tenggelam ke dasar perairan dan bercampur dengan subtrat dasar. Bahan organik yang mengendap di dasar perairan merupakan sumber makanan bagi organisme benthos. Hasil pengukuran kandungan organik sedimen yaitustasiun 1, 1,63 \%, stasiun 2, 1,78\% dan Stasiun 3, 3,86\%.

Tingginya kandungan bahan organik sedimen pada stasiun 3 disebabkan oleh dasar yang berupa padang lamun yang bersubtrat dasar lumpur berpasir dengan gerakan arus yang relatif lebih lambat sehingga diduga terakumulasinya partikel pasir yang lebih halus beserta serasah tumbuhan dan hewan selain itu dari daun maupun ranting mangrove yang membusuk dan terakumulasi pada sedimen. Hal ini juga dapat meningkatkan kandungan bahan organik (Zamroni dan Rohyani, 2008).

Rendahnya kandungan organik yang ditemukan pada stasiun 1 dan 2 diduga karena subtratnya berupa pasir yang lebih kasar dan mendekati tubir berasosiasi dengan karang serta gerakan arus relatif lebih cepat dibandingkan dengan stasiun 3 karena perairannya yang langsung berhubungan dengan laut lepas.

Rendahnya kandungan organik tidak berpengaruh bagi kehidupan teripang, hal ini sejalan dengan pendapat Levinton (1982), bahwa organisme benthik akan memanfaatkan bahan lain yang bernilai nutrisi sebagai makanannya.

\section{Padatan Tersuspensi}

Hasil analisa terhadap padatan tersuspensi berkisar 1,720-1,950 mg/l. Secara umum perairan pantai Desa Kahyapu merupakan pantai dengan tingkat kecerahan $100 \%$. Rendahnya nilai padatan tersuspensi diduga karena lokasi penelitian berhubungan langsung dengan laut lepas yang mempunyai massa air yang tidak banyak dipengaruhi oleh daratan karena tidak ada sungai yang membawa padatan dari daratan. Konsentrasi padatan tersuspensi air laut yang rendah dapat meningkatkan daya tembus sinar matahari lebih besar sehingga meningkatkan aktivitas fotosintesis tumbuhan laut baik mikro maupun macro sehingga oksigen yang dilepaskan tubuhan air menjadi banyak yang bermanfaat untuk kehidupan teripang (Dunton $d k k$., 2003).

Jumlah padatan tersuspensi yang didapat dianggap baik untuk pertumbuhan biota laut yang berada di perairan karena nilainya di bawah nilai toleransi baku mutu dari 
Kementrian Lingkungan Hidup yaitu sebesar 20 mg/l. Menurut Helfinalis (2008), bawah nilai padatan tersuspensi suatu perairan di bawah ambang batas Kementrian Lingkungan Hidup $20 \mathrm{mg} / \mathrm{l}$ dikatakan baik untuk kehidupan biota laut.

\section{KESIMPULAN}

Berdasarkan hasil penelitian ditemukan 7 jenis teripang di perairan Desa Kahyapu Pulau Enggano yaitu teripang selendang (Opheodesoma spectabilis), (Synapta maculata), (Eupta godeffroyi), teripang kalong (Holothuria atra), teripang bakau (Holothuria scabra), teripang pulut (Holothuria leucopspilota) dan teripang benang (holothuria impatiens) yang termasuk kedalam kelas Holothuroidea, dengan dua ordo yaitu Apodida dan Aspidochirotida dan dua famili yaitu Holothuridea dan Synapta serta 4 Genus yaitu Opheodesoma, Synapta, Eupta dan Holothuria.

Pada bulan September maupun November, dominasi teripang di stasiun 1 dan 2 memiliki nilai dominasi jenis tergolong rendah. Pada stasiun 3 bulan September memilki nilai dominasi tergolong tinggi atau ada jenis teripang yang mendominasi dalam komunitas, sedangkan pada bulan November memiliki nilai dominasi tergolong sedang.

Secara Keseluruhan Keanekaragaman teripang di lokasi penelitian menunjukkan tergolong rendah. Keseragaman teripang pada bulan September dan November pada stasiun 1 dan 2 menunjukan keseragaman tergolong tinggi. Pada stasiun 3 bulan September menunjukkan keseragaman tergolong rendah atau tidak beragam, sedangkan pada bulan November menunjukan keseragaman tergolong sedang.

Secara keseluruhan parameter fisika, kimia perairan, kandungan padatan tersuspensi, dan kandungan bahan organik pada bulan September dan November menunjukan kualitas perairan pantai Desa Kahyapu Pulau Enggano dalam keadaan baik untuk pertumbuhan dan perkembangan teripang.

\section{DAFTAR PUSTAKA}

Alaerts, G. dan S. S. Santika. 1984. Metode Penelitian Air. Usaha Nasional. Surabaya. 309 hal.

Al-Rashdi, K. M., S. S. Al-Busaidi and I. H. Al-Rassadi. 2007. Status Of Thesea Cucumber Fishery In The Sultanate Of Oman. SPC Beche de mer information Bulletin 25:1721.

Aziz, A. 1981. Fauna Echinodermata Dari Terumbu Karang Pulau Pari, Kepulauan Seribu. In: Oseonografi di Indonesia. Lembaga Oseanologi Nasional - IPI, Jakarta. (14): 4150 hal.

Basuki, R., S. T. Hartati dan Darmadi. 1999. Penelitian Usaha Perikanan Teripang Melalui Pengkayaan Stok (Setok Enhancement). Balai Penelitian Perikanan Laut. Hal 1-10.

Bappeda Propinsi Bengkulu. 2004. Pengembangan Pulau Enggano Sebagai Pusat Industri Berbasis Maritim dan Pariwisata di Propinsi Bengkulu. Bengkulu.

Bengen, D. G. 2000. Ekosistem dan Sumberdaya Alam Pesisir. Sinopsis. Pusat Kajian Sumberdaya Pesisir dan Lautan. Institut Pertanian Bogor.

Darsono, P. 1995. Sumberdaya Teripang Komersil di Indonesia. Prosid. Sem. Kelautan Nas., (B.M. Ganie, B. Herunadi, A. Alkitri, A. Sudaryanto, N. Hendiarti, eds.) Jakarta 15 - 16 Nopember 1995. Bab II. $7: 1$ - 10.

Darsono, P. 2005. Teripang (Holothuria) Perlu Dilindungi. Bidang Sumberday Laut, Puslit Oseanografi-LIPI. Jakarta. 
Dunton, K, A. Burd, D. Funk, dan R. Maffione. 2003. Linking water turbidity and Total Suspended Solid loading to kelp productivity within the stefannson sound boulder path. Report Prepared by CraigAumack1., MMS Alaska Environmental Studies Program. $86 \mathrm{pp}$

Helfinalis. 1989. Sebaran Foraminifera Bentonik di Perairan Jepara dalam Penelitian Oseanologi Perairan Indonesia Buku I. Lembaga IImu Pengetahuan Indonesia. Jakarta..

Levinton, J. S. 1982. Marine Ecology. Prentice - Hall Inc. Englewood Cliffs, New Jersey. $526 \mathrm{p}$.

Nontji, A. 1993. Laut Nusantara. Penerbit Djambatan. Jakarta. 305 hal.

Odum, E. P. 1971. Fundamental of Ecology. $3^{\text {rd }}$ Eds. W. B. Saunders Company. Philadelphia: $574 \mathrm{p}$.

Suci, W., Melani, R. W. dan Raza'i, S. T. 2012. Struktur Komunitas Moluska Bentik Berbasis TDS (total dissolved solid) Padatan Terlarut dan TSS (Total Suspended solid) Padatan Tersuspensi di Pesisir Perairan Sungai Kawal Kabupaten Bintan Provinsi Kepulauan Riau. Program Studi Manajemen Aquatik Resources, Fakultas IImu Kelautan dan Perikanan, Universitas Maritime Raja Ali Haji. Riau.

Yusron, E. 2003. Sumberdaya teripang (Holothuroidea) di Perairan Teluk Kotania, Seram Barat - Maluku Tengah. Dalam Pesisir dan Pantai Indonesia VIII. Pusat Penelitian dan Pengembangan Oseanologi - LIPI, Jakarta : 129 - 133.

Yusron, E. 2007. Sumberdaya teripang (Holothuroidea) di Perairan Pulau Moti, Maluku Utara. Oseanologi dan Limnologi. Indonesia (33) : 111 - 121 hal.

Wirasti, A. 1990. Beberapa Aspek Ekologi Teripang Keling Holothuria (Halodeine) atra jaeger di Rataan Terumbu Karang Pulau Pari, Pulau Seribu. Skripsi. Universitas Padjajaran. Bandung.

Zamroni, Y. dan Rohyani, I. S. 2008. Produksi Serasah Hutan Mangrove di Perairan Pantai Teluk Sepi, Lombok Barat. Biodiversitas Vol. 9 No. 4, 284-287. 